\title{
Evaluation of the economic efficiency of storage technology for electricity from coal power plants in large-scale chemical batteries
}

ABSTRACT: The article present results of economic efficiency evaluation of storage technology for electricity from coal power plants in large-scale chemical batteries. The benefits of using a chemical lithium-ion battery in a public power plant based on hard coal were determined on the basis of data for 2018 concerning the mining process. The analysis included the potential effects of using a $400 \mathrm{MWh}$ battery to optimize the operation of $350 \mathrm{MW}$ power units in a coal power plant. The research team estimated financial benefits resulting from the reduction of peak loads and the work of individual power units in the optimal load range. The calculations included benefits resulting from the reduction of fuel consumption (coal and heavy fuel oil - mazout) as well as from the reduction of expenses on $\mathrm{CO}_{2}$ emission allowances.

The evaluation of the economic efficiency was enabled by a model created to calculate the NPV and IRR ratios. The research also included a sensitivity analysis which took identified risk factors associated with changes in the calculation assumptions adopted in the analysis into account. The evaluation showed that the use of large-scale chemical batteries to optimize the operation of power units of the subject coal power plant is profitable. A conducted sensitivity analysis of the economic

$\triangle$ Corresponding Author: Piotr Krawczyk; e-mail: pkrawczyk@gig.eu

1 GIG, Poland; ORCID iD: 0000-0003-3184-5383; e-mail: pkrawczyk@gig.eu

2 GIG, Poland; ORCID iD: 0000-0001-5413-6948; e-mail: asliwinska@gig.eu

3 GIG, Poland; ORCID iD: 0000-0002-6614-4707; e-mail: mcwieczek@gig.eu 
efficiency showed that the efficiency of the battery and the costs of its construction have the greatest impact on the economic efficiency of the technology of producing electricity in a coal power plant with the use of a chemical battery. Other variables affecting the result of economic efficiency are the factors related to battery durability and fuels: battery life cycle, prices of fuels, prices of $\mathrm{CO}_{2}$ emission allowances and decrease of the battery capacity during its lifetime.

KEYWORDS: electricity production, energy storage for grid application, lithium-ion battery, evaluation of economic efficiency

\section{Introduction}

The public power industry in Poland is currently based on fossil fuels - mainly coal. Despite some slowdown that has been visible in recent years, the rapid development of the power industry based on renewable power sources - mostly photovoltaic and wind energy is expected (Ministry of Energy 2018). One of the disadvantages of the wind power include instability in terms of electricity supply and the need to provide power reserves in a national power system in the form of power sources based on fossil fuels (Ministry of Energy 2018). Power from renewable sources supplied to a power network combined with changes in the consumer demand result in the operation of a conventional power plant being based on high variability - both annual and daily (Trzmiel 2016). Consequently, the efficiency of electricity production decreases. One of the methods to stabilize the operation of a conventional power plant operating in this mode is to use a high capacity battery. The battery could be used to supply the network with additional volumes of electricity during peak demand hours and to store surplus energy generated during periods of decreased demand.

Increasing interest in storage technologies is primarily expressed by distribution system operators as there is a need to stabilize the operation of the power grid and balance variable supply and demand. The development of large-scale electricity storage technologies is also beneficial for generators of electricity. Combining sources of generation with electricity storage could allow energy units to work at the optimal efficiency point.

There are various ideas where and how to store electricity. Pumped-storage power plants followed by storage using compressed air have been the most widely used so far (Luo et al. 2015; NETL 2008). The battery market is currently growing dynamically, with lithium-ion batteries playing a leading role. The alternative technology is energy storage in the form of hydrogen chemical energy through electrolysis (Komorowska and Gawlik 2018; Chmielniak et al. 2017). However, high hydrogen production costs limit the use of this technology. The benefits include long-term storage, for example of energy generated in summer, which can be used in winter (Ceran 2018). Figure 1 presents energy storage technology depending on the form of stored energy. 


\section{Mechanical}

-PHS (Pumped Hydroelectric Storage)

- CAES (Compressed Air Energy Storage)

-FES (Flywheel Energy Storage)

\section{Electrochemical}

- Secondary battery Lead-Acid/NaS/Li-ion

- Flow battery Redox flow/Hybid flow

\section{Electrical}

- Capacitor/Supercapacitor

-SMES (Superconducting Magnetic Energy Storage)

\section{Thermochemical}

- Solar Fuels

\section{Chemical}

•Hydrogen

\section{Thermal}

- Latent heat storage

Fig. 1. Classification of electricity storage technologies (Luo et al. 2015)

Rys. 1. Klasyfikacja technologii magazynowania energii elektrycznej

The short-term storage of electricity called peak shaving is often based on lithium batteries. The assessment of various electricity storage technologies presented in the paper (Hiremath et al. 2015) indicates that lithium-ion batteries are the most suitable for the power grid. Moreover, the assessment presented in the paper (Terlouw et al. 2019) indicated a positive impact of the lithium-ion batteries such as minimizing expenses and $\mathrm{CO}_{2}$ emission. The review of available literature on lithium-ion batteries is presented in the paper (Peters et al. 2017). The paper (Pellow et al. 2020) is focused on the use of lithium-ion battery in the grid and emphasizes the significant impact of the phase of usage on the results of the assessment of various electricity storage systems. The work (Krupa et al. 2018) presents the forecasted increase in the installed capacity of energy storage in lithium-ion technology in Poland by 2030 from $0.8 \mathrm{MW}$ in 2017 to $410.6 \mathrm{MW}$ in 2030. The main factor determining the development of this area is the increase in the share of PV installations in an electricity grid system. The first lithium-ion energy storage facilities 
created in Poland are $36 \mathrm{kWh}$ in Warsaw (Innogy Group), 1.5 MWh in Puck and $27 \mathrm{MWh}$ in Gdańsk (Energa) (Krupa et al. 2018).

In turn, an increase in the power and capacity of implemented or planned energy storage systems is observed in the world. In 2017, the largest energy storage to date was created using lithium-ion batteries at Hornsdale Wind Farm in Australia. The storage was created to ensure the stability of the electricity grid and to prevent power outages. The $100 \mathrm{MW} / 129 \mathrm{MWh}$ storage facility was constructed by Tesla, Inc. at a cost of USD 50 million. It is owned and operated by Neon.

Tesla is currently working on a new large-scale energy project in California for Pacific Gas and Electric Company (PG\&E) at the Moss Landing Power Plant. The 183 MW/730 MWh installation will be assembled from several hundred Megapack lithium-ion batteries with a capacity of $3 \mathrm{MWh}$ (Tesla). There, Vistra/Dynegy also plans to build a $300 \mathrm{MW}$ storage with a capacity of $1.2 \mathrm{GWh}$ by the end of 2020 (Vistra Energy 2018). In addition, two smaller storages are to be built at the Moss Landing power plant: 75 MW/300 MWh Hummingbird Energy Storage LLC and Micronoc Inc $10 \mathrm{MW} / 40 \mathrm{MWh}$.

AES Alamitos has begun work on creating 400 MWh Fluence Battery Storage System in Long Beach, Southern California for the Alamitos Energy Center (AEC). The storage is set to be launched in 2021. A second similar storage called Strata Solar, $100 \mathrm{MW} / 400 \mathrm{MWh}$, is to be built in Oxnard, southern California. The battery will be made of smaller units of 10 to $40 \mathrm{MW}$ by different manufacturers (AES 2019).

Florida Power \& Light's plans to install 30 million solar panels in Manatee, Florida, by 2030 and in 2021 to build the world's largest $409 \mathrm{MW} / 900 \mathrm{MWh}$ Manatee Energy Storage Center owned by NextEra, which will be solar powered on an industrial scale. The facility will replace two existing 1650 MW gas power plants (FPL 2019; NextEra Energy).

This article presents the results of a technical and economic analysis of the cooperation of power units of a coal power plant with a large-scale chemical battery. The analyzed energy storage should perform a systematic function in a power plant that would balance the ratio of generated and received volumes. Energy storage could be used as a measure to reduce peak loads, adjust load profiles, compensate power losses, load dips on the load side and reactive power. The direct benefit of using such energy storage systems may include the optimization of operation of energy units and therefore a decrease of unit costs of energy production and a decrease of unit emissions of pollutants associated with the energy production process. In addition, the optimization and stabilization of power units will result in their longer service life and lower expenses on ongoing repairs and maintenance. Due to the availability of data, the article is limited to estimating the benefits of reducing fuel costs (coal, mazout) and the purchase of $\mathrm{CO}_{2}$ emission allowances. 


\section{Materials and methods}

\subsection{Description of the analyzed technology}

The subject of the analysis is a $350 \mathrm{MW}$ coal power plant supplying the Polish power system. The analyzed power plant consists of 6 power units with a power input in the fuel of $560 \mathrm{MWt}$ for each dust boiler. Steam from boilers feeds six condensing turbines with rated powers in a unit system: $225 \mathrm{MW}$ (5 turbines) and $220 \mathrm{MW}$ (1 turbine). The turbine rotors are connected by means of a clutch with power generators and work with three cooling towers.

In order to choose a storage technology, in addition to technical criteria such as energy and power density or energy conversion efficiency, the research team took the degree of development, the availability of the technology and, above all, the possibility of working near the operating power plant into account. The analysis covered the process of storing electricity in a battery composed of lithium-ion cells of $100 \mathrm{MW}$ electrical power and a $400 \mathrm{MWh}$ capacity. According to the literature data (Luo et al. 2015; Mongird et al. 2019) the efficiency of such batteries ranges from $77 \%$ up to $97 \%$. In the analyses, the efficiency value from the middle of this range equal to $86 \%$ has been used. As there is a lack of data for large-scale installations, literature data for smaller cells were applied using proportional coefficients. Such an approximation is justified for technological reasons, as high-capacity batteries are constructed from smaller unit cells. For example, Tesla's planned large-scale energy storage at the Moss Landing Power Plant with a capacity of $183 \mathrm{MW} / 730 \mathrm{MWh}$ will be assembled from several hundred Megapack lithium-ion batteries with a capacity of $3 \mathrm{MWh}$.

Due to the high quality and reliability of the source data, the analysis assumes the technology of electricity storage in lithium-ion batteries and the assumptions described in the paper (Ellingsen et al. 2014) for a $253 \mathrm{~kg}$ battery with a capacity of $26.6 \mathrm{kWh}$. The research team decided to use an NCM cell with an aluminum collector coated with lithium-nickel-cobalt-manganese oxide with stoichiometry $\mathrm{Li}\left(\mathrm{Ni}_{1 / 3} \mathrm{Co}_{1 / 3} \mathrm{Mn}_{1 / 3}\right) \mathrm{O}_{2}$ as a cathode, and an anode in the form of a copper collector coated with graphite.

Although the operation of power units is at the disposal of a distribution system operator, this analysis assumes the possibility of cooperation of power units with a hypothetical large scale battery under exclusive conditions. This means that the battery will only serve the power plant included in the analysis presented in this paper. 


\subsection{Data used for the analyses}

The actual operational data for 2018 were used to assess the economic efficiency of the large scale battery electricity storage technology. The following data provided by the power plant operator were used for the analyses:

$\downarrow$ efficiency characteristics of six power units,

$\downarrow$ the operating time and volume of electricity production per hour in 2018 ,

$\downarrow$ fuel consumption of individual power units in 2018,

$\checkmark$ calorific value of coal and auxiliary fuels used in the power plant in the analyzed period.

The total unit construction cost of a large-scale lithium-ion battery was based on the literature data (Mongird et al. 2019) with its value ranging from USD 300/kWh (price level as of the year 2018 ) to USD $100 / \mathrm{kWh}$ (forecasted value in the year 2025). In the analyses the value from the middle of this range, i.e. USD 200/kWh, was applied. With the assumed unit cost of building a battery, its capacity of $400 \mathrm{MWh}$ and a rate of USD $1=$ PLN 3.90, the estimated total cost of building a battery will be about PLN 312 million.

The average cost of fuel (coal and mazout) was assumed on the basis of data made available by the power plant operator for the first half of 2019. The initial purchase price for $\mathrm{CO}_{2}$ emission allowances was adopted on the basis of SPOT quotation on December 4, 2019 on EEX - Primary Market Auction (PL). Assuming the exchange rate of EUR $1=$ PLN 4.30, it amounted to PLN 103.63/Mg CO 2 .

Operating characteristics of power units of the analyzed coal power plant were used to estimate the benefits resulting from the optimization of their operation. These characteristics show dependencies between gross fuel (coal) consumption per unit of electricity produce and unit load. These properties of individual power units of the analyzed power plant are presented in Figure 2.

The optimal operation point of power units is located near the nominal load, about $220 \mathrm{MW}$. This is represented graphically in Figure 3 in the form of averaged characteristics of all active power units of the coal power plant.

\subsection{Assessment methodology}

The basic methodological assumption of the economic efficiency evaluation is the use of large-scale chemical batteries to optimize the electricity production process in the analyzed coal power plant. Based on the analysis of data for 2018 concerning the volume of electricity generation by individual power units, it was found that they often did not work within the optimal load range required to achieve the highest generation efficiency. This was related not only to increased fuel consumption per unit of electricity produced, but also to an increased number of times that boilers are put out of operation and then started again. The relaunch of boilers require additional 


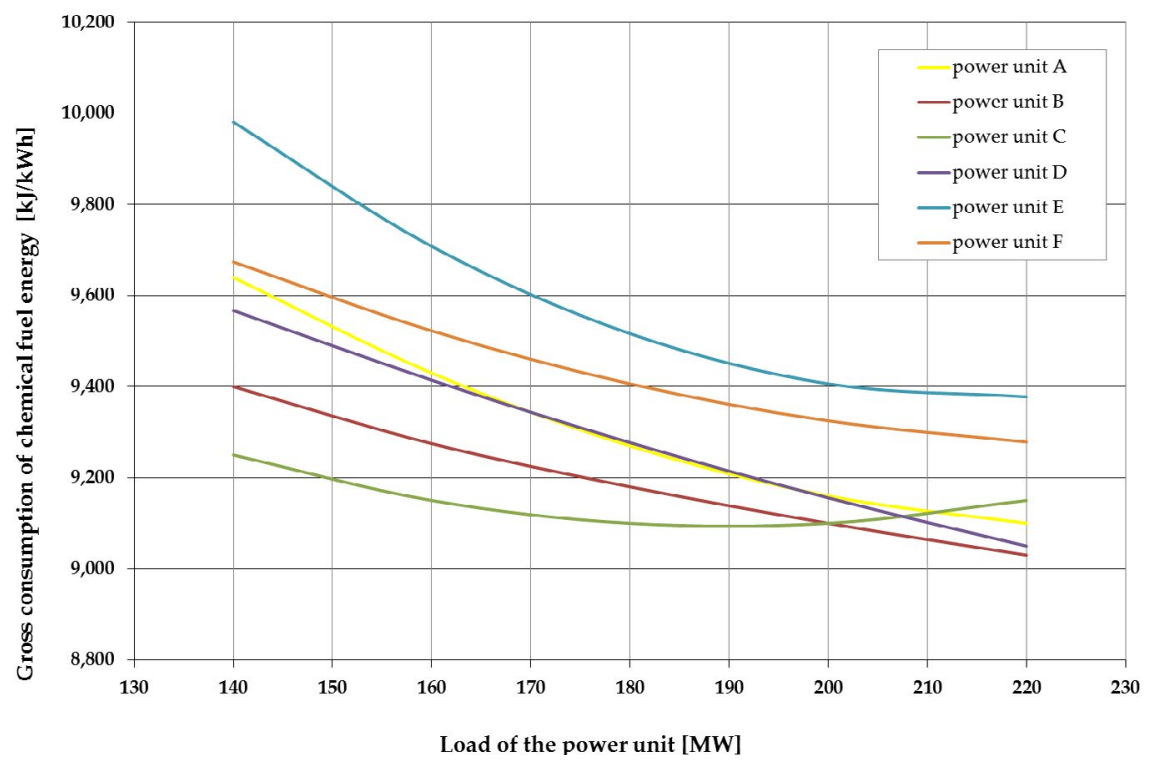

Fig. 2. Operational characteristics of the power units of the analyzed coal-fired power plant Source: own study based on data from the power plant operator

Rys. 2. Charakterystyki eksploatacyjne bloków energetycznych analizowanej elektrowni węglowej

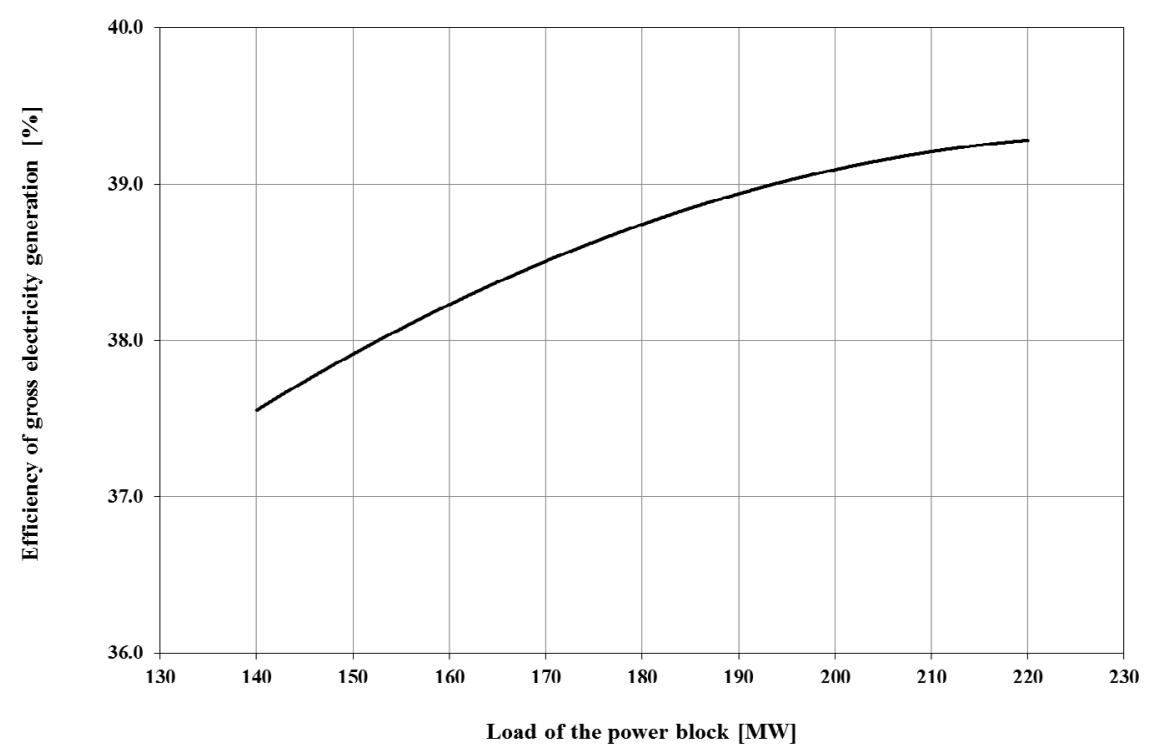

Fig. 3. Dependence of gross efficiency of power units on their load (average of all power units) Source: own study based on data from the power plant operator

Rys. 3. Zależność sprawności brutto bloków energetycznych od ich obciążenia (średnia dla wszystkich bloków energetycznych) 
amounts of fuel, not only coal, but also much more expensive mazout. According to the data of the operator of the analyzed power plant, the additional fuel consumption of power unit associated with the ramp-up after its shutdown is as follows:

४ "hot" ramp-up (the power unit shutdown does not last longer than 8 hours): 68 tons of coal and 23.6 tons of mazout,

४ "warm" ramp-up (the power unit shutdown lasts 8 to 50 hours): 107 tons of coal and 28.1 tons of mazout,

४ "cold" ramp-up (the power unit shutdown is longer than 50 hours): 117.2 tons of coal and 39.5 tons of mazout.

In 2018, the total number of startups of abandoned power units was over 300. Additional fuel consumption for these startups amounted to about $9100 \mathrm{Mg}$ of mazout and about 32,700 Mg of coal. The main reasons for such uneven operation of power units were the fluctuations in electricity demand caused by:

$\checkmark$ daily irregularity in the consumption of electricity by its recipients,

$\downarrow$ uneven and unpredictable production of electricity from renewable sources, mainly wind power.

In 2018 , the maximum hourly values of electricity production reached as much as $206 \%$ of the average daily value. This resulted in the uneven operation of individual power units and periodic shutdown of some of them. This is illustrated by a daily operating profile of the power plant on the selected day of the winter and summer period presented in Figure 4.
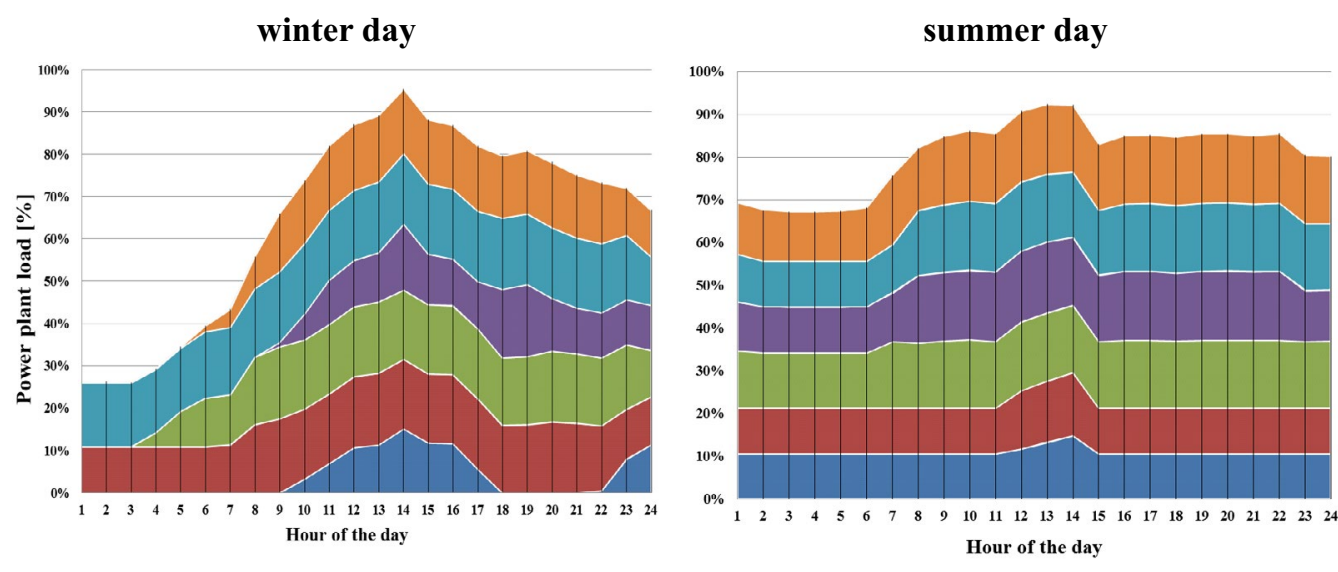

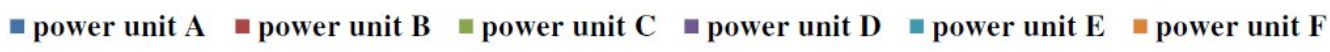

Fig. 4. Power unit operation profile in selected days of the year 2018

Source: own study based on data from the power plant operator

Rys. 4. Profil pracy bloków energetycznych w wybranych dniach roku 2018

The above illustration clearly shows the shutdown phases of individual units and periods of partial load operation. For example, during the summer peak at 2 p.m. all units were operating in 
the load range from 88 to $95 \%$ of the plant's capacity. On the selected day of the winter period, however, there were large fluctuations in the production volume and some power units were shut down. During the night hours, only two units operated within the load range below $30 \%$ of the power plant's capacity. During peak hours between 10 a.m. and 6 p.m. it was necessary to start all the units. Around 2 p.m., they reached over $90 \%$ of the power plant's capacity.

Fluctuations in the load of power units occur throughout the year. Figure 5 presents a profile of the work of the units in 2018, which shows breaks in the operation of individual units and the momentary degree of load.

The functioning of a large-scale chemical battery in the structure of a power plant would stabilize the operation of individual power units. During hours of reduced demand for electricity in the grid, the surplus electricity would be stored in a battery, and in the event of increased demand for electricity, the battery would be a complementary source of electricity, without the need to quickly relaunch the boilers. Therefore, the capacity of the battery was selected so that it fits the maximum difference in the amount of electricity produced, defined as the difference between the daily average calculated from hourly values and the maximum hourly value. In 2018, the total value was approximately $400 \mathrm{MWh}$.

The analyses used the methodology developed by UNIDO (United Nations Industrial Development Organization). This methodology concerns the standardization of project planning, implementation, as well as the activity and effects of the project itself. Here, from the investor's point of view, it is the financial viability of the project that is the overriding criterion in the assessment of the investment. UNIDO recommends the use of discounting methods such as taking the change in value of money over time into account. An investment is defined as the long-term commitment of economic resources to produce and benefit from net profit in the future. Therefore, the discounting of cash flows has become a commonly accepted method of project assessment (Behrens and Hawranek 1991).

In order to determine the economic efficiency of the technology for storing electricity from a coal power plant in large-scale chemical batteries, the Net Present Value (NPV) and the Internal Rate of Return (IRR) of such investment were calculated.

The NPV indicator allows to determine the current value of cash inflows and outflows related to realization of analyzed investment. The result is obtained in monetary units and the following formula was used to calculate it (Marcinek 1997; Sierpińska and Jachna 2000; Rogowski 2018):

$$
N P V=\sum_{i=0}^{n}\left(N C F_{i} \cdot \frac{1}{(1+w)^{i}}\right)
$$

where:

$N C F_{i}-$ annual project cash flow in years $i=0,1,2,3 \ldots n$,

$w \quad-$ discount rate.

The IRR is the interest rate at which the updated value of cash flow is equal to current value of cash flow. This is the interest rate at which the net present value of the analyzed investment is 


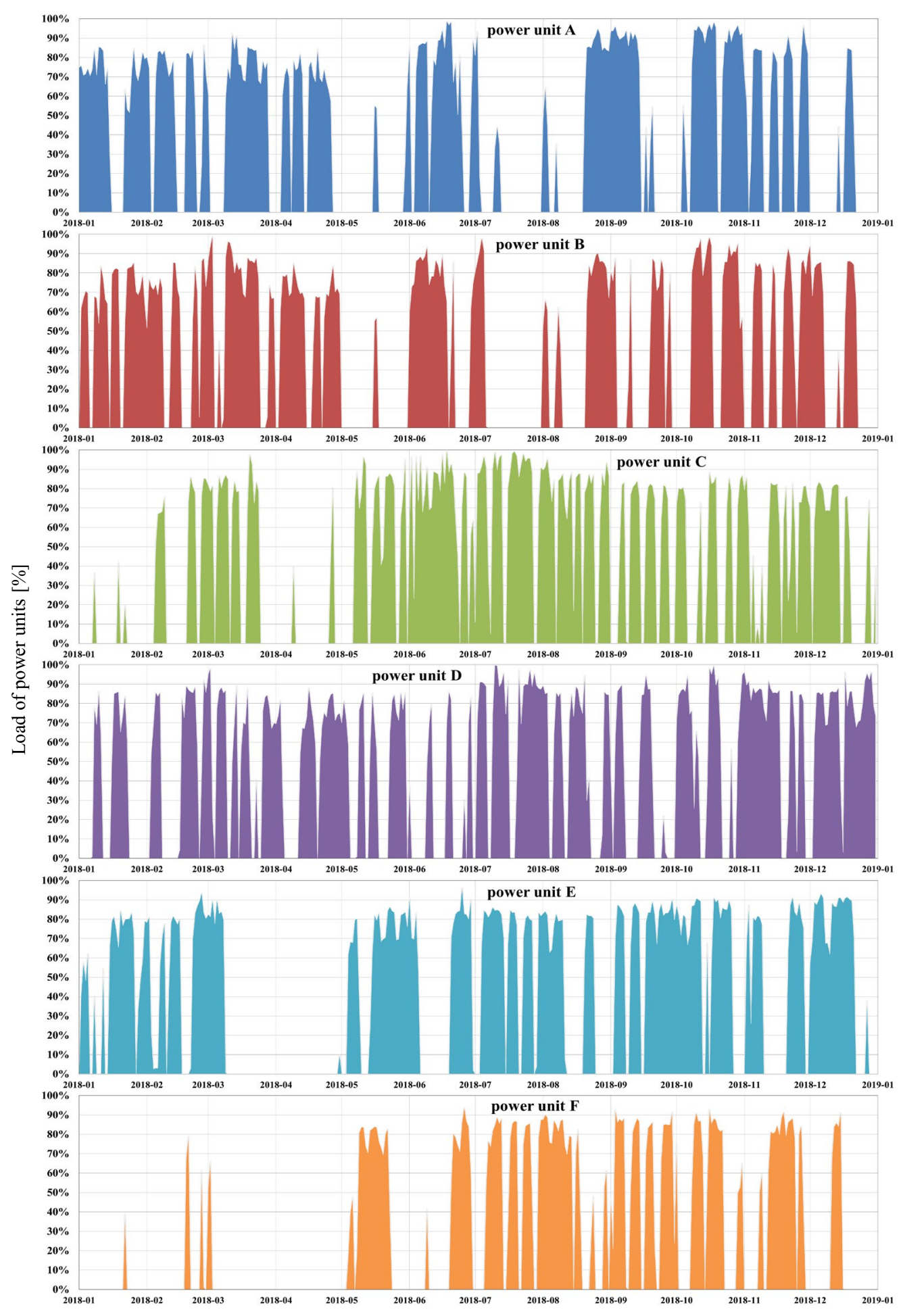


equal to zero $(\mathrm{NPV}=0)$. The IRR therefore directly shows the profitability rate of the investment under analysis. The IRR is calculated from the following formula (Marcinek 1997; Sierpińska and Jachna 2000; Rogowski 2018):

$$
\sum_{i=0}^{n}\left(N C F_{i} \cdot \frac{1}{(1+I R R)^{i}}\right)=0
$$

The following items are included in cash flow:

$\downarrow$ investment expenditure related to the construction of a large-scale chemical battery installation,

$\downarrow$ savings from reduced fuel consumption: the results of improving the efficiency of electricity generation and reducing the number of start-ups of boilers that were shut down,

$\downarrow$ savings resulting from the reduction of expenditure on $\mathrm{CO}_{2}$ emission allowances as a result of the reduced amount of burnt fuels (coal and mazout).

The savings were calculated as the difference between actual fuel consumption for 2018 and the quantities estimated for the operation of a power plant with the battery. It is not possible to estimate the value reliably and therefore the analyses do not include the costs and benefits related to the use of the battery, such as:

- lower costs of repair and maintenance work on power units as a result of improved operating conditions and fewer shutdowns,

$\downarrow$ costs of battery repair and maintenance.

It was assumed that the above costs and benefits would be at a similar level, i.e. they would not have a significant impact on the results of the analyses.

The analysis was performed at fixed rates. This prevented errors due to the uncertainties associated with the available inflation forecasts. Therefore, the calculation uses a discount rate of 5\%, which is recommended by the European Commission for analysis in fixed prices (EC 2015).

At present, there is a lack of long-term operating data on the operation of large-scale chemical batteries in the power industry that would allow the actual lifetime of these devices to be determined. Literature sources determine the lifetime of lithium-ion batteries in the range between 5-16 years (Rydh and Sanden 2005; Chen et al. 2009; Luo et al. 2015; Siedlecki et al. 2015). Based on the these as well, as the level of the technological progress in production of lithium-ion batteries, the 15 -year battery life was assumed in the analyses. Additionally the sensitivity analysis, which examined the impact of the shortened battery life on the economic efficiency assumed in the study, was made.

Along with the number of cycles of battery discharge and recharge, its capacity and efficiency decrease is observed. There is no actual data from long-term operation of the large-scale chemi-

Fig. 5. Load of power units in 2018

Source: own study based on data from the power plant operator

Rys. 5. Obciążenie bloków energetycznych w roku 2018 
cal batteries which would indicate the rate of that process. It is also difficult to determine the relationship between the battery life cycle counted in years and number of discharge and recharge cycles, while taking the decrease in the battery efficiency and capacity into account. Therefore, the impact of the capacity and efficiency decrease in the analyzed large-scale chemical battery on economic efficiency results was examined in the sensitivity analysis.

Changes in fuel prices and $\mathrm{CO}_{2}$ emission allowances were projected for the period covered by the analysis on the basis of available reports (World Bank Group 2019; KOBIZE 2019). The adopted price forecasts are presented in Table 1.

TABLE 1. Forecasts for prices of fuels and $\mathrm{CO}_{2}$ emission allowances

Tabela 1. Prognoza cen paliw i uprawnień do emisji $\mathrm{CO}_{2}$

\begin{tabular}{|c|c|c|c|}
\hline \multirow{2}{*}{ Year } & Prices of $\mathrm{CO}_{2}$ emission allowances & Hard coal prices & Crude oil prices \\
\cline { 2 - 4 } & $\mathrm{EUR} / \mathrm{Mg} \mathrm{CO}_{2}$ & $\mathrm{USD} / \mathrm{mt}$ & $\mathrm{USD} / \mathrm{bbl}$ \\
\hline 2020 & 28.66 & 71.00 & 58.00 \\
\hline 2021 & 31.45 & 69.81 & 59.10 \\
\hline 2022 & 32.00 & 68.65 & 60.22 \\
\hline 2023 & 32.00 & 67.50 & 61.37 \\
\hline 2024 & 29.00 & 66.38 & 62.53 \\
\hline 2025 & 26.00 & 65.27 & 63.72 \\
\hline 2026 & 24.00 & 65.47 & 62.66 \\
\hline 2027 & 21.00 & 65.67 & 61.61 \\
\hline 2028 & 21.00 & 65.87 & 60.56 \\
\hline 2029 & 23.00 & 66.07 & 59.50 \\
\hline 2030 & 27.00 & 60.00 & 70.00 \\
\hline 2031 & 27.00 & 60.00 & 70.00 \\
\hline 2032 & 27.00 & 60.00 & 70.00 \\
\hline 2033 & 27.00 & 60.00 & 70.00 \\
\hline 2034 & 27.00 & 60.00 & 70.00 \\
\hline 2035 & 27.00 & 60.00 & 70.00 \\
\hline
\end{tabular}

Source: World Bank Group 2019; KOBIZE 2019.

The obtained results of the economic efficiency evaluation were analyzed using a sensitivity method. The purpose of the sensitivity analysis is to determine the impact of changes in selected input variables of the bill on the level of economic efficiency indicators of the analyzed electricity storage technology. First, the expected values of these indicators are calculated, which are most realistic under the given conditions of investment uncertainty. Then, the values of successively selected variables are changed and the strength and direction of the impact of these variables on the performance level are examined. Each input variable may change by a certain number of percentage points above or below the expected value whereas other conditions remain 
unchanged. In addition, for each of these revised figures, compared to the baseline scenario, a new value of economic efficiency indicators is calculated. The scope of the analysis is limited to those variables that will have the greatest impact on the result, i.e. the value of the economic efficiency index. These are the so-called critical variables.

The following critical variables identified for the analyzed electricity storage technology were analyzed:

$\checkmark$ changes in capital expenditure related to the construction of a large scale battery: deviations of $\pm 10 \%, \pm 30 \%$ and $\pm 50 \%$,

$\checkmark$ changes in prices of fuels used to produce electricity in the analyzed public power plant (coal and mazout): deviations of $\pm 10 \%, \pm 30 \%$ and $\pm 50 \%$,

$\checkmark$ changes in prices of $\mathrm{CO}_{2}$ emission allowances: deviations of $\pm 10 \%, \pm 30 \%$ and $\pm 50 \%$,

$\downarrow$ battery efficiency: deviations of $\pm 5 \%, \pm 10 \%$ and $\pm 15 \%$,

$\checkmark$ changes in the battery capacity: decrease of the capacity by $5 \%, 10 \%, 15 \%, 20 \%, 25 \%$ and $30 \%$, which corresponds to a battery capacity of $380 \mathrm{MWh}$ to $280 \mathrm{MWh}$,

$\checkmark$ changes in the battery life cycle: decrease of the battery life cycle by $-6.7 \%,-13.3 \%,-20.0 \%$, $-26.7 \%,-33.3 \%$ and $-40.0 \%$, which corresponds to a lifetime of 14 to 9 years.

\section{Analysis results and discussion}

The optimization of the operation of individual power units of the analyzed coal power plant with the use of a large-scale chemical battery allowed to estimate the following financial benefits:

$\checkmark$ reduction of expenses on basic fuel (coal) as a result of improved efficiency of electricity production,

$\checkmark$ reduction of expenses on fuel required to relaunch of boilers as a result of a reduction in the number of shutdowns caused by decreases in demand for electricity in the network,

$\downarrow$ reduction of expenses on the purchase of $\mathrm{CO}_{2}$ emission allowances as a result of reduced fuel consumption (coal and mazout).

As the analyses were conducted on the basis of actual operational data for the year 2018, no active calculation model managing battery operation in real-life operating conditions, was created. It was assumed that at the time when the consumers' demand for electricity is greater than $220 \mathrm{MWh}$, the necessary power units operate under load close to their optimum efficiency range, which is approximately $220 \mathrm{MW}$ (Fig. 2 and Fig. 3). With this assumption only one power unit works under partial load, beyond its optimum efficiency. The battery is therefore used only to level operation of those power unit that works under partial load within a particular time. The calculations assume that the battery equalizes the operation of the power units to the level at which the value of the standard deviation is the lowest. The calculations were based on hourly values, which represent the difference between the actual production volume in 2018 and the multiple of $220 \mathrm{MWh}$. Figure 6 shows the load on these power units considering the battery operation. 
Figure 7 summarizes the electricity production volume of the analyzed power plant with the amounts of electricity assigned to charge the battery and returned from the battery to the power grid.

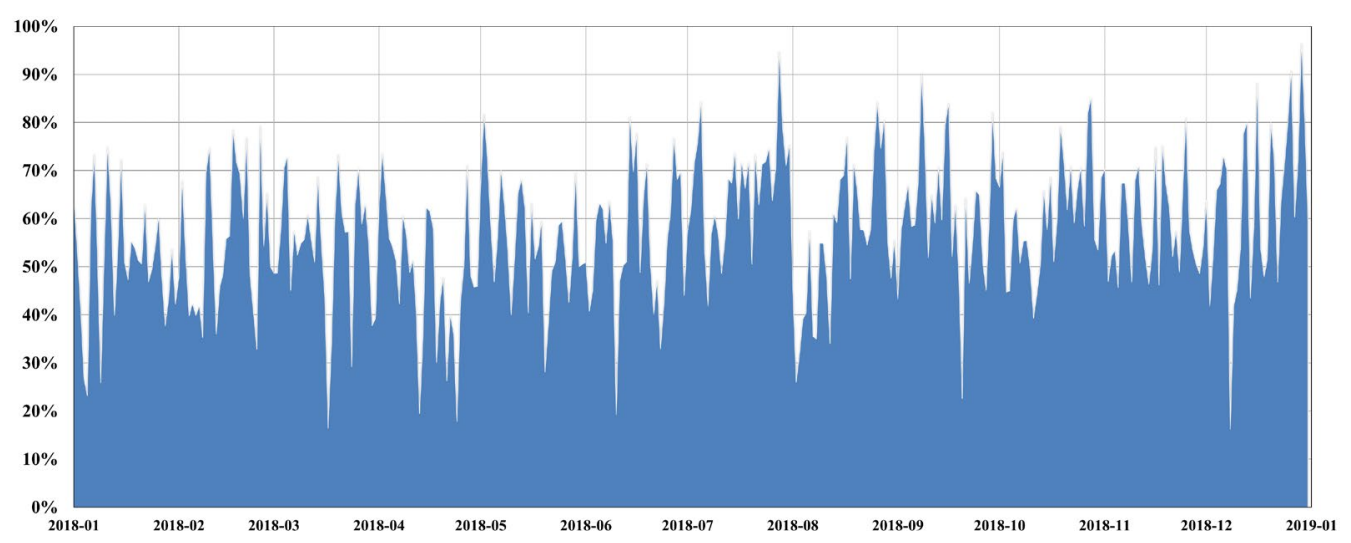

Fig. 6. Load on power units working below the efficiency optimum considering the battery operation Source: own study based on data from the power plant operator

Rys. 6. Obciążenie bloków energetycznych pracujących poniżej optimum sprawnościowego z wykorzystaniem akumulatora

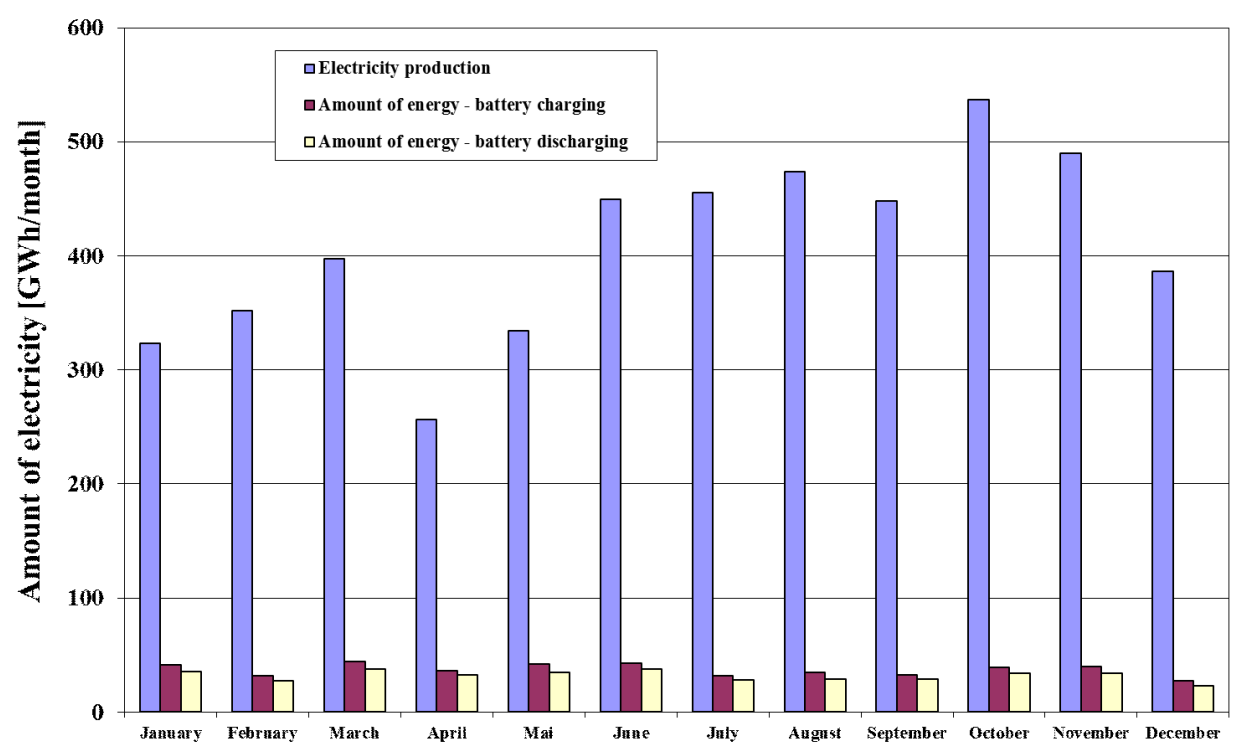

Fig. 7. Comparison of the electricity production volume of the analyzed power plant with the amounts of electricity assigned to charge the battery and returned from the battery to the power grid Source: own study based on data from the power plant operator

Rys. 7. Zestawienie wielkości produkcji energii elektrycznej analizowanej elektrowni z ilościami energii elektrycznej przeznaczanymi do ładowania akumulatora oraz oddawanymi z akumulatora do sieci energetycznej 
Table 2 presents actual operating data for 2018 compared to the estimated fuel consumption when using a large-scale chemical battery in order to optimize the operation of individual power plant units. Calculations for power plant operation based on a battery take electricity losses resulting from the assumed battery efficiency of $86 \%$ into account.

TABLE 2. A list of actual operating data for 2018 with the results of the calculation of fuel consumption

by the power plant using a large-scale chemical battery to optimize the operation of power units

TABELA 2. Zestawienie faktycznych danych eksploatacyjnych za rok 2018 z wynikami obliczeń zużycia paliwa przez elektrownię przy wykorzystaniu chemicznego akumulatora wielkoskalowego do zoptymalizowania pracy bloków energetycznych

\begin{tabular}{|l|c|c|c|c|}
\hline \multicolumn{1}{|c|}{ Item } & Unit & $\begin{array}{c}\text { Operating data } \\
\text { for } 2018\end{array}$ & $\begin{array}{c}\text { Calculations } \\
\text { for power plant } \\
\text { operation using } \\
\text { a battery }\end{array}$ & $\begin{array}{c}\text { Savings in fuel } \\
\text { consumption }\end{array}$ \\
\hline Coal consumption & Mg/year & $2,324,082$ & $2,279,063$ & 45,019 \\
\hline Mazout consumption & Mg/year & 9,131 & 4,760 & 4,371 \\
\hline
\end{tabular}

Source: own calculation based on data from the power plant operator.

The calculated savings in fuel consumption allowed to calculate the reduction of $\mathrm{CO}_{2}$ emissions to the atmosphere. Calculations related to the operation of the power plant using the battery were made based on the correlation between the load of each power unit and the unit consumption of the chemical energy in relation to the unit of electricity produced (Fig. 2). The calculations also included the reduction of fuel consumption for restarting power units (fewer shutdowns). $\mathrm{CO}_{2}$ emission from the power station operating without the battery is the actual operational data for the year 2018.

They are presented in Table 3 . The calculations were based on the actual $\mathrm{CO}_{2}$ emission factors of the analyzed power plant determined on the basis of operating data for 2018 .

Determined savings in fuel consumption and reduction of $\mathrm{CO}_{2}$ emission were used to calculate the monetary benefits generated by the battery applied to optimize the operation of power plant units. The results are presented in Table 4.

NPV and IRR efficiency ratios were calculated on the basis of calculated investment spending on the construction of the battery and the financial benefits resulting from its use. Cash flows for one-year investment realization period and 15-year exploitation period are presented in Table 5.

Based on the cash flows presented in Table 4, the following values of economic efficiency ratios were calculated:

$\downarrow \mathrm{NPV}=\mathrm{PLN} 57.54$ million,

$\uparrow \operatorname{IRR}=7.7 \%$.

The obtained results indicate that the use of a large-scale chemical battery to optimize the operation of power units in a public coal power plant is economically efficient under the adopted calculation assumptions. The NPV indicator takes a positive value and the IRR indicator is higher than the discount rate used in the calculation. It should be noted, however, that the economic 
TABLE 3. The ecological effect of using a large-scale chemical battery to optimize the operation of power units in terms of reducing emission of $\mathrm{CO}_{2}$ into the atmosphere

TABELA 3. Efekt ekologiczny wykorzystania chemicznego akumulatora wielkoskalowego do zoptymalizowania pracy bloków energetycznych w zakresie redukcji emisji $\mathrm{CO}_{2}$ do atmosfery

\begin{tabular}{|c|c|c|c|}
\hline No. & Item & Unit & Value \\
\hline 1 & $\begin{array}{l}\text { Unit } \mathrm{CO}_{2} \text { emission in the process of coal combustion in the analyzed } \\
\text { power plant }\end{array}$ & $\mathrm{Mg} \mathrm{CO}_{2} / \mathrm{Mg}$ coal & 1.98 \\
\hline 2 & Savings in coal consumption & $\mathrm{Mg} /$ year & 45,019 \\
\hline 3 & $\begin{array}{l}\text { Avoided } \mathrm{CO}_{2} \text { emissions from coal combustion due to battery use } \\
(\text { No. } 1 \times \text { No. } 2)\end{array}$ & $\mathrm{Mg} \mathrm{CO}_{2} /$ year & $89,151.08$ \\
\hline 4 & $\begin{array}{l}\text { Unit } \mathrm{CO}_{2} \text { emission in the process of burning mazout in the analyzed } \\
\text { power plant }\end{array}$ & $\mathrm{Mg} \mathrm{CO}_{2} / \mathrm{Mg}$ mazout & 3.33 \\
\hline 5 & Savings in mazout consumption & $\mathrm{Mg} /$ year & 4,371 \\
\hline 6 & $\begin{array}{l}\text { Avoided } \mathrm{CO}_{2} \text { emissions from mazout combustion due to battery use } \\
(\text { No. } 4 \times \text { No. } 5 \text { ) }\end{array}$ & $\mathrm{Mg} \mathrm{CO}_{2} /$ year & $14,555.76$ \\
\hline 7 & $\begin{array}{l}\text { Total avoided } \mathrm{CO}_{2} \text { emissions from fuels combustion due to battery } \\
\text { use }\end{array}$ & $\mathrm{Mg} \mathrm{CO}_{2} /$ year & $103,706.84$ \\
\hline
\end{tabular}

Source: own calculation based on data from the power plant operator.

TABLE 4. Financial benefits of a large-scale chemical battery applied to optimize the operation of power units generated by increased efficiency of electricity generation and reduced emission of $\mathrm{CO}_{2}$ into the atmosphere

TABELA 4. Korzyści finansowe wykorzystania chemicznego akumulatora wielkoskalowego do zoptymalizowania pracy bloków energetycznych w wyniku zwiększenia efektywności wytwarzania energii elektrycznej i redukcji emisji $\mathrm{CO}_{2}$ do atmosfery

\begin{tabular}{|l|c|c|c|}
\hline \multirow{2}{*}{ Item } & Unit price & $\begin{array}{c}\text { Reduction } \\
\text { of consumption/ } \\
\text { /emissions }\end{array}$ & Financial benefits \\
\cline { 2 - 4 } & PLN/Mg & Mg/year & PLN mln /year \\
\hline Benefits of reducing coal consumption & 300 & 45,019 & 13.51 \\
\hline Benefits of reducing mazout consumption & $1,800.00$ & 4,371 & 7.87 \\
\hline Benefits of reducing $\mathrm{CO}_{2}$ emissions & 103.63 & 103,707 & 10.75 \\
\hline \multicolumn{2}{|l|}{} & 32.12 \\
\hline
\end{tabular}

Source: own calculation based on data from the power plant operator.

efficiency is decisively influenced by the amount of savings on the purchase of $\mathrm{CO}_{2}$ emission allowances. Otherwise the construction and use of a large scale battery would not be cost-effective due to insufficient reduction in fuel consumption resulting from its use. After taking the losses related to the assumed battery efficiency into account, the amount of coal burned decreases only by about $1.9 \%$. 
TABLE 5. Cash flows for the purpose of calculating NPV and IRR economic efficiency ratios of electricity storage technology from a coal power plant in a large-scale chemical battery

TABELA 5. Przepływy pieniężne na potrzeby wyliczenia wskaźników efektywności ekonomicznej NPV i IRR technologii magazynowania energii elektrycznej z elektrowni węglowej w wielkoskalowym akumulatorze chemicznym

\begin{tabular}{|c|c|c|c|c|c|}
\hline $\begin{array}{c}\text { Year of } \\
\text { Analysis }\end{array}$ & $\begin{array}{c}\text { Capital } \\
\text { expenditures for } \\
\text { the construction } \\
\text { of a battery } \\
\text { [PLN mln] }\end{array}$ & $\begin{array}{c}\text { Savings in fuel (coal) } \\
\text { expenses related to the } \\
\text { use of the battery } \\
\text { [PLN mln] }\end{array}$ & $\begin{array}{c}\text { Savings in fuel } \\
\text { (mazout) expenses } \\
\text { related to the use of } \\
\text { the battery } \\
\text { [PLN] }\end{array}$ & $\begin{array}{c}\text { Savings } \\
\text { in expenses for } \\
\text { purchasing CO } \\
\text { emission allo- } \\
\text { wances } \\
\text { [PLN mln] }\end{array}$ & $\begin{array}{c}\text { Cash flow } \\
\text { [PLN mln] }\end{array}$ \\
\hline 2020 & 312.00 & 0.0 & 0.0 & 0.0 & -312.00 \\
\hline 2021 & 0.00 & 15.49 & 8.46 & 14.02 & 37.98 \\
\hline 2022 & 0.00 & 15.23 & 8.62 & 14.27 & 38.13 \\
\hline 2023 & 0.00 & 14.98 & 8.79 & 14.27 & 38.04 \\
\hline 2024 & 0.00 & 14.73 & 8.95 & 12.93 & 36.62 \\
\hline 2025 & 0.00 & 14.48 & 9.12 & 11.59 & 35.20 \\
\hline 2026 & 0.00 & 14.53 & 8.97 & 10.70 & 34.20 \\
\hline 2027 & 0.00 & 14.57 & 8.82 & 9.36 & 32.76 \\
\hline 2028 & 0.00 & 14.62 & 8.67 & 9.36 & 32.65 \\
\hline 2029 & 0.00 & 14.66 & 8.52 & 10.26 & 33.44 \\
\hline 2030 & 0.00 & 13.32 & 10.02 & 12.04 & 35.38 \\
\hline 2031 & 0.00 & 13.32 & 10.02 & 12.04 & 35.38 \\
\hline 2032 & 0.00 & 13.32 & 10.02 & 12.04 & 35.38 \\
\hline 2033 & 0.00 & 13.32 & 10.02 & 12.04 & 35.38 \\
\hline 2034 & 0.00 & 13.32 & 10.02 & 12.04 & 35.38 \\
\hline 2035 & 0.00 & 13.32 & 10.02 & 12.04 & 35.38 \\
\hline
\end{tabular}

Source: own calculation.

A sensitivity analysis was conducted in order to thoroughly analyses the impact of particular calculation assumptions and operating data on the results of economic efficiency of battery usage. The results show how the critical variables listed in the description of the methodology influence the obtained NPV values. The results are given in Table 6 and Figure 8 presents a graphical interpretation of the obtained calculation results.

The results of the sensitivity analysis allow to determine the following hierarchy of the impact of the analyzed critical variables on the economic efficiency of battery usage in a coal power plant:

1) changes in battery efficiency,

2) changes in battery construction costs,

3) changes in battery life cycle,

4) changes in coal and mazout prices,

5) changes in prices of $\mathrm{CO}_{2}$ emission allowances,

6) changes in battery capacity. 
TABLE 6. Results of sensitivity analysis for storage technology of electricity from a coal power plant in a large-scale chemical battery

TABELA 6. Wyniki analizy wrażliwości dla technologii magazynowania energii elektrycznej z elektrowni węglowej w wielkoskalowym akumulatorze chemicznym

\begin{tabular}{|c|c|c|c|c|c|c|c|c|}
\hline Analyzed variable & Unit & \multicolumn{7}{|c|}{$\begin{array}{l}\text { Deviations from the initial value and resulting values } \\
\text { for individual deviations }\end{array}$} \\
\hline \multicolumn{9}{|c|}{ Sensitivity to changes of capital expenditures - battery construction cost } \\
\hline Deviations from the initial value & $\%$ & -50 & -30 & -10 & 0 & 10 & 30 & 50 \\
\hline $\begin{array}{l}\text { The unit cost of battery } \\
\text { construction }\end{array}$ & $\begin{array}{l}\mathrm{USD} / \\
\mathrm{kWh}\end{array}$ & 100 & 140 & 180 & 200 & 220 & 260 & 300 \\
\hline NPV & PLN mln & 213.54 & 151.14 & 88.74 & 57.54 & 26.34 & -36.06 & -98.46 \\
\hline \multicolumn{9}{|c|}{ Sensitivity to changes of fuel prices (coal and mazout) } \\
\hline Deviations from the initial value & $\%$ & -50 & -30 & -10 & 0 & 10 & 30 & 50 \\
\hline $\begin{array}{l}\text { Coal price - the prices level from } \\
\text { the first year of the analysis }\end{array}$ & $\mathrm{PLN} / \mathrm{Mg}$ & 175 & 245 & 315 & 350 & 385 & 455 & 525 \\
\hline $\begin{array}{l}\text { Mazout price - the prices level } \\
\text { from the first year of the analysis }\end{array}$ & PLN/Mg & 950 & 1,330 & 1,710 & 1,900 & 2,090 & 2,470 & 2,850 \\
\hline NPV & PLN mln & -64.56 & -15.72 & 33.12 & 57.54 & 81.96 & 130.80 & 179.64 \\
\hline \multicolumn{9}{|c|}{ Sensitivity to changes of prices of $\mathrm{CO}_{2}$ emission allowances } \\
\hline Deviations from the initial value & $\%$ & -50 & -30 & -10 & 0 & 10 & 30 & 50 \\
\hline $\begin{array}{l}\text { Price of } \mathrm{CO}_{2} \text { emission allowances } \\
\text { - the prices level from the first } \\
\text { year of the analysis }\end{array}$ & $\begin{array}{c}\text { euro/Mg } \\
\mathrm{CO}_{2}\end{array}$ & 14.33 & 20.06 & 25.79 & 28.66 & 31.53 & 37.26 & 42.99 \\
\hline NPV & mln PLN & -5.13 & 19.94 & 45.01 & 57.54 & 70.07 & 95.14 & 120.21 \\
\hline \multicolumn{9}{|c|}{ Sensitivity to changes of battery efficiency } \\
\hline Deviations from the initial value & $\%$ & -15 & -10 & -5 & 0 & 5 & 10 & 15 \\
\hline Battery efficiency & $\%$ & 73.1 & 77.4 & 81.7 & 86.0 & 90.3 & 94.6 & 98.9 \\
\hline NPV & PLN mln & -143.01 & -68.73 & -2.27 & 57.54 & 111.66 & 160.85 & 205.77 \\
\hline \multicolumn{9}{|c|}{ Sensitivity to decrease of the battery capacity } \\
\hline Deviations from the initial value & $\%$ & 0 & -5 & -10 & -15 & -20 & -25 & -30 \\
\hline Battery capacity & MWh & 400 & 380 & 360 & 340 & 320 & 300 & 280 \\
\hline NPV & PLN mln & 57.54 & 52.43 & 47.31 & 42.20 & 37.08 & 31.97 & 26.85 \\
\hline \multicolumn{9}{|c|}{ Sensitivity to decrease of the battery life cycle } \\
\hline Deviations from the initial value & $\%$ & 0 & -6.7 & -13.3 & -20.0 & -26.7 & -33.3 & -40.0 \\
\hline Battery life cycle & years & 15 & 14 & 13 & 12 & 11 & 10 & 9 \\
\hline NPV & PLN mln & 57.54 & 40.52 & 22.65 & 3.89 & -15.81 & -36.50 & -58.22 \\
\hline
\end{tabular}

Source: own calculation.

The obtained results also indicate that the loss of economic efficiency of the analyzed battery technology for optimization of coal power plant operation occurs with relatively small deviations assumed in the calculation of critical variables. These are the following values for each critical variable: 


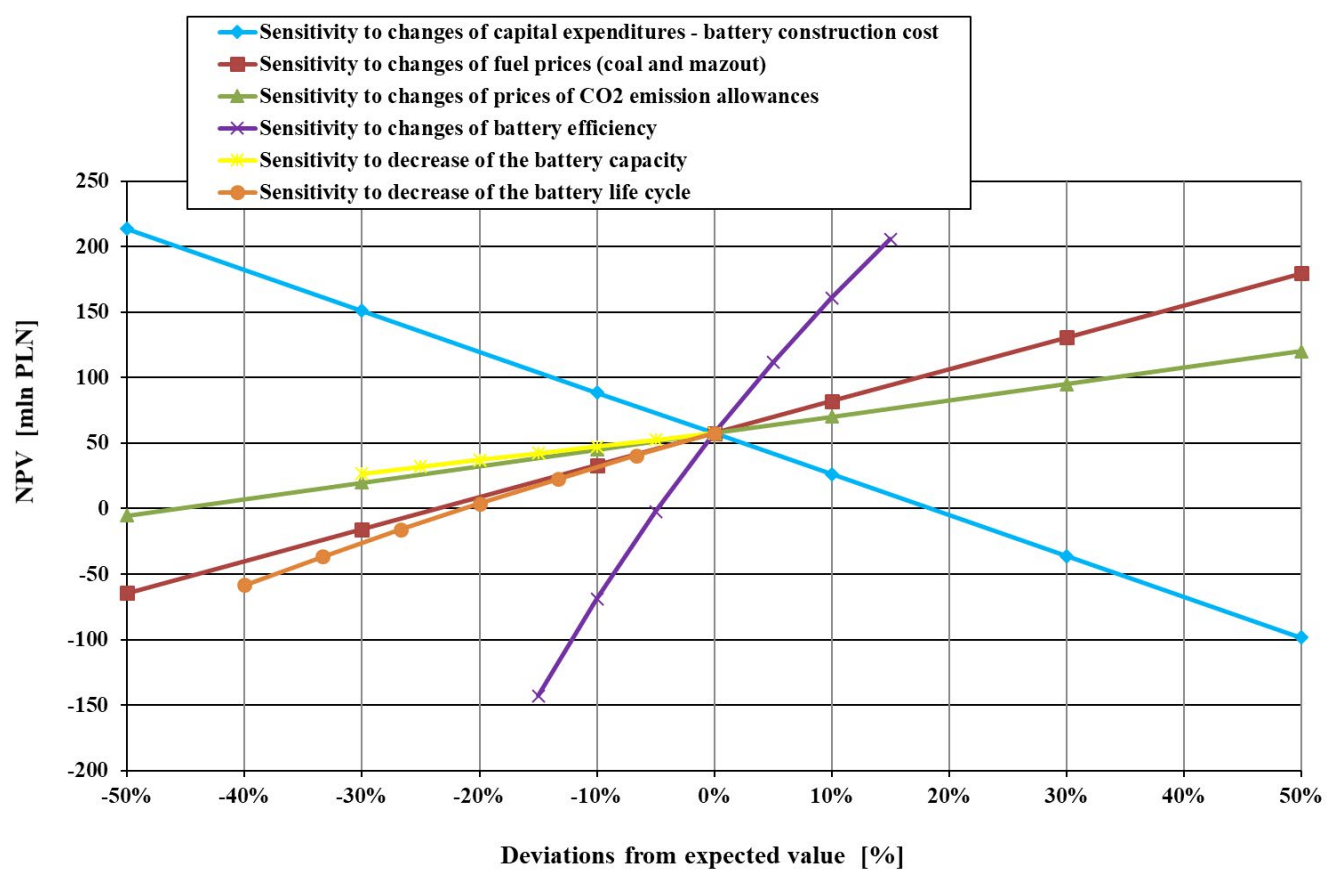

Fig. 8. Graphical interpretation of the results of sensitivity analysis for storage technology of electricity from a coal power plant in a large-scale chemical battery Source: own study

Rys. 8. Interpretacja graficzna wyników analizy wrażliwości dla technologii magazynowania energii elektrycznej z elektrowni węglowej w wielkoskalowym akumulatorze chemicznym

a) decrease in battery efficiency to about $81.9 \%$,

b) increase in the cost of building a battery to about USD $237 \mathrm{kWh}$,

c) decrease in battery life cycle to 11 years,

d) decrease in coal and mazout prices by about $23.56 \%$,

e) decrease in $\mathrm{CO}_{2}$ emission allowance prices to about EUR 15.51/Mg $\mathrm{CO}_{2}$.

The obtained results indicate which directions of development and promotion of electric energy accumulation technologies should be adopted by a public power facility. 


\section{Conclusion}

The economic analysis-together with the assumed calculation assumptions-gives positive results of effectiveness expressed by NPV and IRR indicators:

$\checkmark \mathrm{NPV}=\mathrm{PLN} 57.54$ million,

$\diamond \operatorname{IRR}=7.7 \%$.

The results show that savings on the purchase of $\mathrm{CO}_{2}$ emission allowances should be included in the calculations as they decisively influence on the level of economic efficiency. This is due to a slight reduction in fuel consumption as a result of using the battery to optimize the operation of power units in a power plant. After taking the losses of electricity related to the assumed battery efficiency into account, the amount of coal burned decreases only by about $1.9 \%$. Since in the last few years there has been a significant increase in the prices of $\mathrm{CO}_{2}$ emission allowances (from about EUR 5/Mg CO 2 in 2017 to over EUR 25/Mg CO 2 in 2019), and the forecasts presented in the KOBIZE report (KOBIZE 2019) do not assume that their prices will fall below EUR 20/Mg in the 2030, the use of batteries may be very economically viable in the future. Moreover, technological progress in the field of electricity storage and the spread of this technology will contribute both to an increase in the efficiency of batteries and a reduction in the unit investment in their construction. Given the development of renewable energy sources, which is characterized by the instability of the electricity supply and the existing volatility of demand from electricity consumers, the use of large scale batteries in a coal power plant to stabilize the operation can be considered a very beneficial solution.

The conducted sensitivity analysis of the economic efficiency of the technology of electricity production in a coal power plant with the use of a chemical battery allows the impact of particular variables on the obtained analysis results to be assessed. This allows to indicate which criteria decide about the profitability of development projects related to the analyzed use of large-scale electricity storage facilities based on lithium-ion batteries. The efficiency of the battery and the costs of its construction have the greatest impact on the economic efficiency of the technology of producing electricity in a coal power plant with the use of a chemical battery. Other variables affecting the result of economic efficiency are the factors related to battery durability and fuels: battery life cycle, prices of fuels, prices of $\mathrm{CO}_{2}$ emission allowances and the decrease of the battery capacity during its lifetime.

This publication has been financed by the Ministry of Science and Higher Education, Poland, grant number: 10174019 


\section{References}

AES 2019. AES Breaks Ground on 400 MWh Energy Storage Project in Southern California Fluence Battery Storage System to Provide Sustainable, Reliable Energy for Southern California Edison Customers [Online] https://www.aes.com/investors/press-releases/press-release-details/2019/AES-Breaks-Groundon-400-MWh-Energy-Storage-Project-in-Southern-California/default.aspx [Accessed: 2019-01-17].

BeHrENs, W. and HAWRANEK, P.M. 1991. Manual for the preparation of industrial feasibility studies. Vienna: United Nations Industrial Development Organization.

Ceran, B. 2018. A comparative analysis of energy storage technologies. Polityka Energetyczna - Energy Policy Journal Vol. 21, Iss. 3, pp. 97-110.

Chen et al. 2009 - Chen, H., Cong, T.N., YAng, W., TAn, C., Li, Y. and Ding, Y. 2009. Progress in electrical energy storage system: a critical review. Progress in Natural Science: Materials International 19, pp. 291-312.

Chmielniak et al. 2017 - Chmielniak, T., Lepszy, S. and MońkA, P. 2017. Hydrogen energy - main problems (Energetyka wodorowa - podstawowe problemy). Polityka Energetyczna - Energy Policy Journal Vol. 20, Iss. 3, pp. 55-66 (in Polish).

EC 2015. Guide to Cost-Benefit Analysis of Investment Projects. Economic appraisal tool for Cohesion Policy 2014-2020 (Przewodnik po analizie kosztów i korzyści projektów inwestycyjnych. Narzędzie analizy ekonomicznej polityki spójności 2014-2020). Brussels: European Commission, Directorate-General for Regional and Urban Policy (in Polish).

Ellingsen et al. 2014 - Ellingsen, L.A-W., Majeau-Bettez, G., Singh, B., Srivastava, A.K., Valøen, L.O. and Strømman, A.H. 2014. Life cycle assessment of a lithium-ion battery vehicle pack. Journal of Industrial Ecology 18, pp. 113-124.

FPL 2019. FPL announces plan to build the world's largest solar-powered battery and drive accelerated retirement of fossil fuel generation. [Online] http://newsroom.fpl.com/2019-03-28-FPL-announces -plan-to-build-the-worlds-largest-solar-powered-battery-and-drive-accelerated-retirement-of-fossil-fuel-generation [Accessed: 2019-01-17].

Hiremant et al. 2015 - Hiremant, M., Derendorf, K. and Vogt, T. 2015. Comparative life cycle assessment of battery storage systems for stationary applications. Environmental Science \& Technology 49, pp. $4825-4833$.

KomorowsKa, A. and GaWLik, L. 2018. Management of surplus electricity production from unstable renewable energy sources using Power to Gas technology. Polityka Energetyczna - Energy Policy Journal Vol. 21, Iss. 4, pp. 43-64.

KOBIZE 2019. $\mathrm{CO}_{2}$ market report No. 91, October 2019 (Raport z rynku $\mathrm{CO}_{2} \mathrm{Nr}$ 91, październik 2019). [Online] https://www.kobize.pl/pl/file/2019/id/141/raport-z-rynku-co2-pazdziernik-2019 [Accessed: 2019-11-15] (in Polish).

Krupa et al. 2018 - Krupa, K., Nieradko, Ł. and HaraziŃski, A. 2018. Prospects for energy storage in the world and in Poland in the 2030 horizon. Polityka Energetyczna - Energy Policy Journal Vol. 21, Iss. 2, pp. 19-34.

Luo et al. 2015 - Luo, X., WAng, J., Dooner, M. and Clarke, J. 2015. Overview of current development in electrical energy storage technologies and the application potential in power system operation. Applied Energy 137, pp. 511-536.

MARCINEK, K. 1997. Financial assessment of investment projects of companies (Finansowa ocena przedsięwzięć inwestycyjnych przedsiębiorstw). Katowice: University of Economics Publishing House, 115 pp. (in Polish).

Ministry of Energy 2018. Energy policy of Poland to 2040 - project (Polityka energetyczna Polski do 2040 r. - projekt). Warszawa [Online] https://www.gov.pl/documents/33372/436746/PEP2040_ 
projekt_v12_2018-11-23.pdf/ee3374f4-10c3-5ad8-1843-f58dae119936 [Accessed: 2020-03-10] (in Polish).

Mongird et al. 2019 - Mongird, K., Fotedar, V., Viswanathan, V., Koritarov, V., Balducci, P., HadJerioua, B. and Alam, J. 2019. Energy Storage Technology and Cost Characterization Report. U.S. Department of Energy.

NETL 2008. Market Analysis of Emerging Electric Energy Storage Systems. National energy technology laboratory and Department of Energy report with code DOE/NETL-2008/1330 of July 31, 2008 [Online] http://www.netl.doe.gov/energy-analyses/refshelf/PubDetails.aspx?Action=View\&PubId=212 [Accessed: 2020-03-10].

NextEra Energy. [Online] www.nexteraenergy.com [Accessed: 2019-01-17].

Pellow et al. 2020 - Pellow, M.A., Ambrose, H., Mulvaney, D., Betita, R. and Shaw, S. 2020. Research gaps in environmental life cycle assessments of lithium ion batteries for grid-scale stationary energy storage systems: End-of-life options and other issues. Sustainable Energy Technologies and Assessments 2, DOI: 10.1016/j.susmat.2019.e00120.

Peters et al. 2017 - Peters, J.F., Baumann, M., Zimmermann, B., Braun, J. and Weil M. 2017. The environmental impact of Li-Ion batteries and the role of key parameters - A review. Renewable \& Sustainable Energy Reviews 67, pp. 491-506.

Rogowski, W. 2018. Investment effectiveness account (Rachunek efektywności inwestycji). Warszawa: Wydawnictwo Nieoczywiste, 670 pp. (in Polish).

RYDH, C.J. and SANDEN, B.A. 2005. Energy analysis of batteries in photovoltaic systems - part II: Energy return factors and overall battery efficiencies. Energy Convers Manage 46(11-12), pp. 1980-2000.

Siedlecki et al. 2015 - Siedlecki, M., Galant, M., Fuć, P. and Lijewski, P. 2015. The comparison of battery performance in lithium-ion technology for use in electric vehicle drivetrains (Porównanie parametrów użytkowych akumulatorów w technologii litowo-jonowej stosowanych w uktadach napędowych pojazdów elektrycznych). Logistyka 3, pp. 4340-4349 (in Polish).

SiERPIŃSKA, M. and JACHNA, T. 2000. Company assessment according to global standards (Ocena przedsiębiorstwa wedtug standardów światowych). Warszawa: PWN, 277 pp. (in Polish).

Tesla. [Online] https://www.tesla.com/megapack [Accessed: 2019-01-17].

Terlouw et al. 2019 - Terlouw, T., AlSkaif, T., Baure, C. and SARK, W. van 2019. Multi-objective optimization of energy arbitrage in community energy storage systems using different battery technologies. Applied Energy 239, pp. 356-372.

TrZmiel, G. 2016. Instability problem of a wind energy and energy storage (Problem niestabilności energetyki wiatrowej a magazynowanie energii). Poznań University of Technology Academic Journals: Electrical Engineering No 87, pp. 83-95 (in Polish).

Vistra Energy 2018. Vistra Energy to Develop 300-Megawatt Battery Storage Project in California. [Online] https://investor.vistraenergy.com/investor-relations/news/press-release-details/2018/Vistra-Energy-to-Develop-300-Megawatt-Battery-Storage-Project-in-California/default.aspx [Accessed: 2019-01$-17]$.

World Bank Group 2019. Commodity Markets Outlook. Washington: World Bank [Online] https://openknowledge.worldbank.org/handle/10986/32633 [Accesed: 2019-11-15]. 


\section{Ocena efektywności ekonomicznej technologii magazynowania energii elektrycznej z elektrowni węglowej w wielkoskalowych akumulatorach chemicznych}

\section{Streszczenie}

Artykuł przedstawia wyniki oceny efektywności ekonomicznej technologii magazynowania energii elektrycznej z elektrowni węglowej w wielkoskalowych akumulatorach chemicznych. Na podstawie danych eksploatacyjnych za rok 2018 oszacowano korzyści z wykorzystania chemicznego akumulatora litowo-jonowego przez elektrownię zawodową opalaną węglem kamiennym. Przeanalizowane zostały potencjalne efekty zastosowania akumulatora o pojemności $400 \mathrm{MWh}$ do optymalizacji pracy bloków energetycznych elektrowni węglowej o mocy $350 \mathrm{MW}$. Oszacowano korzyści finansowe, będące efektem redukcji obciążeń szczytowych oraz pracy poszczególnych bloków energetycznych w optymalnym zakresie ich obciążenia. W obliczeniach uwzględniono korzyści wynikające ze zmniejszenia zużycia paliw (węgla i mazutu) oraz wynikające ze zmniejszenia wydatków na zakup praw do emisji $\mathrm{CO}_{2}$.

W celu oceny efektywności ekonomicznej zbudowano model, w którym wyliczono wskaźniki NPV i IRR. Przeprowadzono też analizę wrażliwości uwzględniającą zidentyfikowane czynniki ryzyka związane ze zmianami przyjętych założeń obliczeniowych. Przeprowadzona analiza wykazała opłacalność stosowania wielkoskalowych akumulatorów chemicznych do optymalizacji pracy bloków energetycznych elektrowni węglowej. Przeprowadzona analiza wrażliwości wykazała, że największy wpływ na efektywność ekonomiczną technologii produkcji energii elektrycznej w elektrowni węglowej z wykorzystaniem akumulatora chemicznego ma sprawność akumulatora, a w następnej kolejności koszty jego budowy. Kolejne zmienne wpływające na wynik efektywności ekonomicznej to czynniki związane z trwałością akumulatora i paliwami: okres eksploatacji akumulatora, ceny paliw, ceny praw do emisji $\mathrm{CO}_{2}$ emitowanego w wyniku ich spalania i spadek pojemności akumulatora w okresie jego eksploatacji.

SŁOWA KLUCZOWE: produkcja energii elektrycznej, magazynowanie energii elektrycznej do zastosowania w sieci, baterie litowo-jonowe, ocena efektywności ekonomicznej 
